\title{
Zhang Junmai's Early Political Philosophy and the Paradoxes of Chinese Modernity
}

\author{
Eric S. NELSON*
}

\begin{abstract}
This article examines the significance of reflexive self-critical modernity in the development of early "New Confucianism" by reconsidering the example of Zhang Junmai in the context of the May Fourth and New Culture Movements. Whereas these movements advocated scientific rationality and thorough Westernization, Zhang's education and research in Germany before and after the First World War led him to a critical perspective on Western modernity informed by its contemporary crisis tendencies and Western philosophical and social-political critics. Zhang adopted elements from German Idealism, life-philosophy, and social democracy to critique the May Fourth and New Culture Movements and reconstruct the "rational core" and ethical sensibility of Confucian philosophy. Zhang's "self-critical modernity" was oriented toward a moral and social-political instead of a scientific and technological vision of Westernization. Zhang's position was condemned by New Culture champions of scientific modernity who construed Zhang's position as reactionary metaphysics beholden to the past without addressing his self-critical interpretation of modernity that adopted early twentieth century Western critiques of the spiritual and capitalist crisis-tendencies of modernity. In response to this complex situation, Zhang articulated a phenomenological interpretation of the social-political, ethical, and cultural lifeworld, drawing on classic and contemporary Chinese and Western sources, which endeavoured to more adequately address the paradoxes of Westernization and modernization, and the crisis of Chinese ethical life.
\end{abstract}

Keywords: Zhang Junmai, modernity, May Fourth Movement, lifeworld, rationality, democratic socialist politics

\section{Zgodnja politična filozofija ZhangJunmaija in paradoksi kitajske modernosti Izvleček}

Besedilo proučuje pomen reflektivne samokritične modernosti v razvoju zgodnjega "novega konfucianizma«, in sicer na primeru ponovne obravnave Zhang Junmaija v kontekstu gibanja četrtega maja in novih kulturnih gibanj. Medtem ko so se intelektualci

Eric S. NELSON, Professor of Humanities at Hong Kong University of Science and Technology.

Email address: esnels@gmail.com

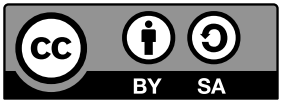


v gibanjih zavzemali za znanstveno racionalnost in popolno vesternizacijo, je Zhanga izobraževanje in raziskovanje $\mathrm{v}$ Nemčiji pred prvo svetovno vojno in po njej usmerilo h kritičnemu pogledu na zahodno modernost, ki sta ga oblikovali sočasni kriza in zahodna filozofska ter družbenopolitična kritika. Zhang je v kritiko gibanja četrtega maja in novih kulturnih gibanj uvedel elemente nemškega idealizma, filozofije življenja in socialne demokracije ter rekonstruiral »racionalno jedro « in etično senzibilnost konfucijanske filozofije. Zhangova »samokritična modernost« je usmerjena k moralnemu in družbenopolitičnemu pogledu in ne $\mathrm{k}$ znanstveni in tehnološki viziji vesternizacije. Zagovorniki nove kulture znanstvene modernosti so Zhangovo trditev imeli za nazadnjaško metafiziko, ki je zavezana preteklosti, pri čemer niso upoštevali njegove samokritične interpretacije modernosti, ki je sprejela zahodno kritiko duhovnih in kapitalističnih kriznih tendenc modernosti z začetka 20. stoletja. Kot odziv na te kompleksne razmere je Zhang oblikoval fenomenološko interpretacijo družbenopolitičnega, etičnega in kulturnega življenjskega sveta, ki črpa iz klasičnih in sodobnih kitajskih in zahodnih virov in si prizadeva za bolj enakovredno obravnavo paradoksov vesternizacije in modernizacije ter krize etičnega življenja na Kitajskem.

Ključne besede: Zhang Junmai, moderna, gibanje četrtega maja, življenjski svet, racionalnost, socialnodemokratska politika

\section{Introduction: The May Fourth Movement and the Question of Modernity ${ }^{1}$}

The historian Yu Ying-shih 余英時 described in his recent memoir (Yu Ying-shib buiyi lu 余英時回憶錄) how slowly the idea of a “May Fourth Movement” (wusi yundong 五四運動) was disseminated. Yu narrates an anecdote from the diary of $\mathrm{Hu}$ Shi 胡適, dated July 24, 1922, in which $\mathrm{Hu}$ expressed his dismayed surprise about how many students, while taking college entrance examinations, had no conception of what the May Fourth Movement was and signified (Yu 2018, 25).

A more radical interpretation might contend that the very idea of the May Fourth Movement is a retrospective historical construction by, initially, the intellectuals of the "New Culture Movement" (xin wenhua yundong 新文化運動) in their totalizing polemic against traditional culture, and subsequently by a Chinese communism that constructed its origins from the sprouts of progressive May Fourth ideas. ${ }^{2}$ Despite the identification of the iconoclasm of the May Fourth and New Culture

1 I would like to thank Shengqing Wu and Tze-ki Hon for their comments on earlier versions of this paper.

2 On the "totalistic antitraditionalism" of the May Fourth era, see Lin 1979. On the historical connections between the May Fourth Movement and communism, see, for instance, the work on Guo Moruo 郭沫若 by Chen 2007. 
Movements with the Communist war against tradition as feudalistic, which culminated in the Cultural Revolution (wenhua dageming 文化大革命), a theme we will return to below, significant differences remain (see Zhang 1952, 47).

The varied reception of the May Fourth Movement, which has been interpreted as a model for the Communist and Cultural Revolutions as well as the June 4,1989 and more recent democratic protest movements, over the last hundred years discloses how it has been constructed and reconstructed for a variety of intellectual, cultural, and social-political purposes. ${ }^{3}$ An initial problem in considering the idea of May Fourth is its belatedness and reinterpretation according to the imperatives and needs of a plurality of different competing discourses. Edmund S. K. Fung introduced distinctions between traditionalism and modern conservativism in Republican China, further distinguishing between cultural and political forms of conservativism (Fung 2009, 777-813; see also Fung 2010). Yet if the multiplicity of overlapping distinctive trends and tendencies are to be adequately differentiated, the narrative of Westernizing progressive versus conservatives and traditionalists is in need of a more fundamental complication and revision (cf. Fang 2019, 106). This first nexus of issues concerns the belatedness, constructed formation, and multiple purposes of "May Fourth". A second concerns the dangers of "Whig History" and the reductive levelling of progressive interpretations.

Wang Fan-sen 王汎森 argued in a recent article that the May Fourth Movement signifies a mixed period (or "confused period") that should be interpreted as a network or sematic field rather than as a transition in a linear progression (Wang $2019,18-31)$. We can draw from his discussion how this field of forces concentrated around questions of: (1) Enlightenment and revolution; (2) freedom, equality, and lifeview; and (3) colonialism and capitalism.

The identification of the May Fourth Movement with Western ideas of progress and modernization, and its critics with traditionalism and conservatism, is a prominent feature of both initial proponents and subsequent accounts. Modernity, progress, and Westernization are deeply value-laden and not neutral, objective or scientific expressions. They presuppose the narrative of a necessary progress that relies on problematic teleological (and thus metaphysical) presuppositions about the goal-oriented nature of history and the perfectibility of the human species.

As critical social theorists from Adorno and Horkheimer to Foucault have revealed, naïve progressive histories face the danger of constructing a "Whig history" in which this movement is interpreted as inevitably progressing towards the

3 For extensive discussions of the problems of interpreting the significance of May Fourth, see Chow, Hon, Ip, and Price 2008. 
achievement of a specific conception of enlightenment and freedom (Horkheimer and Adorno 2002). ${ }^{4}$ The Whig approach to history is not accidental, given the reliance on Victorian conceptions of science and scientific progress among prominent New Culture intellectuals—such as Hu Shi and Ding Wenjiang 丁文江一 who appealed to Western advocates of the positivist program of a comprehensive scientization of culture such as W. K. Clifford, T. H. Huxley, and Herbert Spencer, as well as more recent thinkers such as John Dewey and his instrumentalist reinterpretation of the positivist paradigm. ${ }^{5}$

There are consequently two interconnected forms of reductionism to be addressed: the reductive account of modernity and Chinese modernity, and the positivist reduction of culture to science and life to instrumental rationality and technique. Hu could write to an American friend in 1924 and assert in his debate over life-philosophy and scientism that: "We are here living over the days of Huxley and W. K. Clifford" (Hu 2007, 225; Egan and Zhou 2009, 176). According to $\mathrm{Hu}$, the new culture is a struggle of science against religion, superstition, andfollowing its positivist denigration-metaphysics. Science is understood in terms of Darwinistic pragmatism, according to which progress signifies the increasing instrumental adaptation to and manipulation of the environment.In line with his Victorian and pragmatist sources — and unlike Rudolf Carnap and the emerging logical positivism of the Vienna Circle that was concerned with the question of science's social value and radically demarcated scientific and non-scientific questions ${ }^{6}$ - Hu's pragmatist naturalism could not adequately address the normative and interpretive complexity of the social-political and ethical "lifeworld", which would be developed in Zhang's works, and consequently issues such as the naturalistic misconception of deriving norms from facts and the extent to which a "naturalistic" scientific life-attitude and culture concern the question of the value of the sciences rather than scientific truth.

\section{The Complexity of Chinese Modernities}

The Whig progressive versus conservative narrative is required by its own logic to oversimplify and marginalize the cases of intellectuals who diverge from this

$4 \quad$ A classic account of Whig history is found in Butterfield 1931. On the May Fourth movement and the discourse of Enlightenment, see Schwarcz 1986.

5 On Dewey, Hu, and the modernization of China, see Tan 2003; Tan 2012, 23-44; Wang 2007; Zhang 2010.

6 On the complexity of Carnap's relation to life-philosophy, see Nelson 2018b, 321-46; and Nelson 2013, 151-56. 
reductive narrative and who are simultaneously traditional and modern, "conservative" and "progressive" in different respects. Recent historical works have demonstrated the traditionalism of modernizers and the modernity of conservative traditionalists in Republican China. ${ }^{7}$ Furthermore, as we will consider here, there are modernizing intellectuals who offer different conceptions of what it means to be modern and of the relation between modernity and the past. There is thus a need to consider the multiplicity and conflict of interpretations over what it signifies to be "modern" in Western as much as in Chinese contexts and discursive formations.

Accordingly, I would like to reconsider an alternative example, or case-study, that throws the prominent homogenizing narratives of modernity and Chinese modernity into question, indicating the potential for a more complex, differentiated, and nuanced account of the May Fourth Movement, its consequences, and its contemporary significance.

The philosopher, political activist, and public intellectual Zhang Junmai 張君勱 (birth name: Zhang Jiasen 張嘉森, 1886-1969), also known as Carsun Chang in the Western world, has had two receptions: one as a moral and cultural conservative follower of Liang Qichao 梁啟超 defending “oriental civilization”, and the other as a tenacious advocate of constitutionalism, democracy, and a socialist mixed economy. ${ }^{8}$ Zhang's example indicates the problematic status of standard narratives of modern Chinese history. He is typically yet inappropriately-given his progressive politics and modernistic intercultural appropriation of Chinese traditions-categorized in discussions of his Confucianism as a "conservative" or "neoconservative" critic and opponent of the May Fourth Movement who engaged in disputes with significant representatives of the New Culture Movement such as-in the polemical response against his lecture on "lifeview" (Lebensanschauung; rensheng guan 人生觀) at Tsinghua University (清華大學) on February 14, 1923-Hu Shi, Ding Wenjiang, Chen Duxiu 陳獨秀, and Wu Zhihui 吳稚暉. ${ }^{9}$ Drawing on contemporary European life-philosophical and Neo-Kantian sources that had established a demarcation between science and lifeview, Zhang articulated the difference between lifeviews (which presuppose the affective, ethical, and cultural dimensions of human life) and scientific discourses that were ignored in the positivist and pragmatist enthusiasm of New Culture intellectuals.

7 There is a new wave of reexamination of the complexity of tradition and modernity in modern China, see for instance $\mathrm{Wu} 2013$.

8 For an overview of Zhang's thought and its relationship with German and intercultural philosophy, see chapter two of Nelson 2017.

9 These essays are gathered in two different collections, including one by Zhang (Zhang 1924). 
The construction of Zhang as a conservative anti-May Fourth intellectual could only be perceived to be legitimate from a perspective that homogenizes modern Chinese intellectual history. Zhang actively advocated a progressive form of politics, namely, a democratic constitutional socialism, from World War One to his lectures on socialism near the end of his life (Shehui zhuyi sixiang yundong gaiguan 社會主義思想運動概觀), and critiqued the proposals associated with the May Fourth and New Culture Movements from a "leftist" socialist perspective as well as the so-called "rightist" perspectives of life-philosophy and Confucian ethical-political thought (Zhang 2015). ${ }^{10}$

Assessments emphasizing Zhang's conservative political sensibility neglect his life-long commitment to democratic socialism. Zhang personally met, corresponded, and learnt from German social democratic intellectuals and politicians_-including key figures such as Eduard Bernstein, Karl Kautsky, and Philipp Heinrich Scheidemann - as he described in a 1928 essay on his political impression of traveling and studying in Europe from 1919 to 1921 (Zhang 1928, 21-24). He studied law with the Marxist Karl Korsch (a pioneering figure of "Western Marxism") as well as philosophy with the idealist life-philosopher Rudolf Christoph Eucken in Jena, with whom he co-wrote Das Lebensproblem in China und Europa (Zhang 2015, 2; Korsch 2001, 1147; Zhang and Eucken 1922).

In the same period as Zhang engaged in the life and science controversy, in which he articulated a position closer to Wilhelm Dilthey than to his teacher Eucken in defending the human sciences (Geisteswissenschaften) and the role of freedom in the cultivation of a lifeview (Lebensanschauung), he was an exponent of contemporary German social democratic and British labour social-political thought that he helped introduce to China in his 1920 essay on the respective merits of German social democracy vis-à-vis Soviet communism (Zhongguo zhi qiantu: Deguo hu? Eguo hu? 中國之前途：德國乎? 俄國乎?), and his 1922 report on German social democracy (Xin Deguo shehui minzhu zhengxiang ji 新德國社會民主政象 記) (Zhang 1922b). He engaged with British socialist theory in a 1928 essay on the prominent left-leaning British labour theorist Harold Laski, published in the anti-nationalist and anti-communist alternative socialist magazine The New Way (Xinlu 新路) that he co-edited and which was suppressed by the Nationalist authorities, and a 1930 translation, under the name Zhang Shilin 張士林, of $A$ Grammar of Politics (Zhengzhi dianfa 政治典範) (Zhang 1928b, 35-36; Zhang 1930b). Laski would be a key figure for democratic socialism in the developing world (notably, Jawaharlal Nehru in India) and the China Democratic League

10 On Zhang's socialism, see Jeans 1997. On the relation between his conceptions of Confucian ethics and politics of freedom, see Guo 2017. 
(Zhongguo minzhu tongmeng 中國民主同盟), with his influence seen in members such as the ill-fated advocate of individual rights Chu Anping 儲安平, who had studied with Laski at the London School of Economics (Wong 1993, 457-90).

In this article, I will examine the relevance of Zhang's thinking to an intercultural phenomenology (in the wider sense of this expression) of the lifeworld, rationality, and democratic socialist politics. Zhang's social-political writings from the 1920s to 1940s reveal a noteworthy Chinese and intercultural contribution to a phenomenology of cultural and social-political life. He engaged in debates over the best route to the socialization of the means of production and society, advocating the role of ethical and democratic steering in socialization in contrast to its totalitarian imposition. Zhang offers ways of interculturally contesting and rethinking the social philosophies of Edmund Husserl and Jürgen Habermas, as he oriented the goals of the realization of socialism and democracy in relation to the concrete realities of the Chinese form of historical life, which offers an alternative way of conceptualizing the lifeworld to classical phenomenology, and which he depicted through a life-philosophical and phenomenological interpretation that emphasized its implicit rationality, intercultural openness, and historical transformability. ${ }^{11}$ Zhang's commitments to constitutionally guaranteed political and social rights and democratic rule and socialization indicate that a more complex and multifaceted history of Chinese modernity - in which specifically modern radically democratic incarnations of Confucianism are possible-is needed in contrast to homogenous narratives that contend that modernity can have only one (whether constructed according to liberal or communist preconceptions) hegemonic form.

\section{Zhang Junmai in the Wake of May Fourth 1919}

Republican China began politically in 1912 with the fall of the Qing Dynasty. Yet it is "May Fourth 1919" that signifies the irrevocable cultural and social breakthrough of the West and modernity into Chinese life. There are multiple interpretations of the events associated with May Fourth, 1919 and its highly contested implications for Chinese modernization. Zhang offers us a multifaceted example to reconsider the question of May Fourth and modernity.

11 Zhang was one of the first authors to discuss Husserl in Chinese, but does not appear directly influenced by him. Nonetheless, his approaches to issues of rationality, historical life, and crisis shares historical sources and affinities with phenomenology as developed in Husserl. For more on Zhang and European thought, cf. chapter two of Nelson 2017. On Husserl, Habermas, and intercultural philosophy, see chapter six. 
One way of contextualizing the construction of his image as an anti-May Fourth conservative is to return to the archives and historical records. Zhang's initial comments are developed in "China and the League of Nations" published on Oct 23, 1919 in the Hong Kong based English language newspaper South China Morning Post (Zhang 1919). In this short piece balancing the nationalism of the student movement and an international legal and ethical order that would protect the weak (Republican China) from the powerful (Imperial Japan), Zhang endorsed the aims and aspirations of the students, maintaining that the Chinese people had supported the allied cause and the Wilsonian idea of internationalism in World War I and were opposed to the League of Nations due to the unjust settlement that transferred German colonial interests in Shandong to the Japanese.

Zhang's 1919 discussion occurs within the context of Chinese modernity, interpreted as a formation of tensions and contestations instead of as a homogenous unity. They concern building a modern nation-state, as Zhang employed concepts of national self-interest and the realization of a just international political order. ${ }^{12}$

Zhang would remain sympathetic to what he described as the primary significance of the 1919 student movement in contrast to its later reinterpretations and appropriations by the New Culture and Communist movements. It was an expression of the needs and aspirations of the Chinese people for autonomy and respect. In "Modernization of China and Revival of the Philosophy of the Confucian School", a 1965 lecture in South Korea, he noted how its hidden meaning was how the Chinese youth demanded radical transformations for the sake of transforming China into a modern nation state (Zhang 1965, 91).

Zhang's commitment to two fundamental demands of the historic May Fourth Movement, namely, anti-colonial nationalism and the introduction of democracy without the tutelage of one political party, remains operative throughout his political writings and is noticeable in his philosophical works.

O. Brière S. J. remarked in Fifty Years of Chinese Philosophy, 1898-1950 that: "Chang Chun-mai was a partisan of state socialism: for him, the nation comes first, and socialism itself is subordinate to it. But his idealistic socialism is aligned more closely with the Communist party than with the Kuomintang” (Briere, 1956, 31). To be more precise, as glimpsed in his 1919 article and as more fully elucidated in his 1930s writings advocating a Chinese form of democratic socialism, nationalism signified both: (1) a pragmatic imperative of realistic international politics to preserve and assert national interests, which China had failed to follow to its near destruction; and (2) a normative model of collective flourishing to critique actually

12 On the context of the idea of nation building, see Hon 2015. 
existing conditions and encourage their active transformation through the development of constitutional democracy, socialist planning and steering of the economy that drew on Western and Soviet models, and a renewed Confucian ethos that drew on and dialogically engaged Western sources without merely passively receiving and imitating them. ${ }^{13}$ It is important to consider how "Western modernity" is at best a heuristic and more often a myth given the multiplicity of Western modernities that were re-interpreted, negotiated, and transformed in the "non-Western" (an expression that perpetuates the idea of the asymmetrical separation of the "West") colonial and quasi-colonial (such as Republican China) periphery.

\section{Nationalism, Autonomy, and Self-Power in Zhang's Reading of Fichte and Spinoza}

The nationalist leader Sun Yat-sen 孫逸仙 had in his 1924 lecture "Nationalism and Cosmopolitanism", published in Sanmin zhuyi 三民主義 (The Three Principles of the People), defended the anti-colonial nationalism of oppressed peoples against the false universality of colonial cosmopolitanism (Sun 1996). Zhang's nationalism likewise addressed an oppressed and scattered people. This is evident in his writings on the German philosopher Johann Gottlieb Fichte published in 1926 and 1932. In the 1926 article "The Patriotic Philosopher: Fichte" (Aiguo de zhexuejia: Feixide 愛國的哲學家: 菲希德), the Germany of 1808 is interpreted as a failed state (it is a multiplicity of conflicting states) suffering from Napoleonic invasion and national crisis (Zhang 1926, 71-77). Zhang begins by drawing parallels between the 1808 German and 1926 Chinese situation, interpreting Fichte's Addresses to the German Nation (Reden an die deutsche Nation (1808)) as a call for autonomy, on the one hand, and on the other a patriotic popular movement for national rebirth (zaisheng 再生, which would become the name of the journal titled National Renaissance in English) that could mobilize a semi-colonized, beleaguered, and abject nation (see Mittler 2018, 102-3).

In his 1926 Fichte article, Zhang's argumentation follows the themes of Fichte's Addresses and deploys the Kantian language of autonomy, concluding that there is a need for the radical reform of Chinese life in three areas: (1) education, (2) morality, and (3) national spirit (minzu jingshen 民族精神) and patriotism (aiguo yuanli 愛國原理).

13 Zhang was a leading figure in a number of political parties and movements during the Republican era, including the Chinese State Socialist Party (Zhongguo guojia shehui dang 中國國家社會 黨), the Chinese Democratic League (Zhongguo minzhu tongmeng 中國民主同盟), the Chinese Democratic Socialist Party (Zhongguo minzhu shehui dang 中國民主社會黨). On Zhang's socialist politics, see Jeans 1997. 
First, education is described in a Kantian language, in particular in Kant's essay "What is Enlightenment?" (1784) as requiring the cultivation of autonomy that necessitates a thorough self-examination and self-critique to escape from a self-produced and self-imposed tutelage. Although a process of Enlightenment is not lacking in Chinese history, and Chinese Enlightenment thought was for him one of the sources of the European Enlightenment, the Chinese people lacked autonomy. National education is consequently construed as a political education in individual freedom that was currently lacking in Chinese historical life.

Secondly, moral-reformation counters an internally produced and self-imposed illness and degeneration that has been created by oneself and one's own motivations. Moral reform of a crisis-ridden form of life can occur through a reconstruction of morality and the formation of a "new self" and a new national spirit in which self-respect and self-love can flourish, as well as love for others and a new sense of public community.

Finally, third, self-interested and selfish concerns have led the Chinese people into colonial slavery and tutelage. New motivations of "national spirit" and "patriotism" require overcoming merely personal individual concerns, including the ownership of property, and the development of one's own power and own character. Independence is achieved through a focus on social rather than merely individual fulfilment (Zhang 1926, 71-77).

The concept of the individual and collective development of autonomy and "self-power", gained in engagement with the "activist idealism" of Kant, Fichte, and Eucken and reinterpreted in relation to Neo-Confucian thinkers such as Wang Yangming 王陽明, are key underlying concerns of Zhang's interpretation and appropriation of modern Western philosophy in the 1920s and 1930s. Zhang connected the Kantian notion of autonomy, the defining concept of political liberalism according to John Rawls and Jürgen Habermas, during this period with the notion of increasing self-generative power, a concept-as Hannah Arendt has demonstrated - that has significant roles and an interconnected history in republican and fascist political thought (Habermas 1995, 109-31; Arendt 1968). This problematic of "self-determination" (Selbstbestimmung) is visible in Fichte's political thought and its reception. ${ }^{14}$

14 Fichte had sympathized with the republicanism of the French Revolution in his Contribution to the Correction of the Public's Judgments Regarding the French Revolution (Beitrag zur Berichtigung der Urteile des Publikums über die französische Revolution (1793)) and, after his disillusionment with French imperialism, called in the Addresses for national mobilization against the occupying French forces. Fichte's The Closed Commercial State (Der geschlossene Handelsstaat (1800)) proposed the idea of a self-sufficient planned national economy. On the complexity of Fichte's nationalism, see James 2015; Kohn 1949, 319-43. 
Zhang was familiar with the contemporary German reception of Fichte in Eucken and Hans Driesch, and appears aware of the contested political dimensions and implications of Fichte's political thought. Zhang's Jena teacher and collaborator Eucken had utilized-like Husserl in his 1917 Lectures on "Fichte's Ideal of Humanity" (Fichtes Menschheitsideal) -Fichte's Addresses in The Bearers of German Idealism (Die Träger des deutschen Idealismus (1915)) to defend a nationalist vision of German spirit during the First World War (Husserl 1987, 267-95; Husserl 1995, 111-33). Zhang had accompanied the pacifist and liberal neo-vitalist philosopher Hans Driesch during his 1922 stay in China, collaborating with Qu Shiying 㫿世英 on translating lectures that included one centred on Fichte's Doctrine of Scientific Knowledge (Wissenschaftslehre (1795)). ${ }^{15} \mathrm{He}$ also noted the reverential, religious attitude of German National Socialism toward Fichte's Addresses in his 1932 forward to his selected translation (Fichte, 1932). ${ }^{16}$ The fascist, communist, and social democratic receptions of Fichte emphasized in their own ways his ideas of practical activism, economic planning, and self-determination that likewise are of primary concern in Zhang's interpretation. ${ }^{17}$

The relation of autonomy and power is addressed again in 1932 in relation to Spinoza's political thought. Hu Shi and Zhang Junmai contributed essays to a 1932 collection on Spinoza, Dem Andenken Spinozas (In Remembrance of Spinoza) that included German and Chinese texts, in honour of the three hundredth anniversary of the philosopher's birth ( $\mathrm{Hu}$ 1932).$^{18}$ Both authors were operating within the confines and pressures of the censorship of the Nationalist regime. Hu's essay compared Spinoza and Zhuangzi as pantheistic philosophers. Hu avoided directly discussing politics, and concluded by interpreting wuwei 無爲 as non-interference and keeping to one's own affairs. Similar to Hu's contribution, Zhang played with Daoist language and images in his essay. Unlike $\mathrm{Hu}$, however, he did not focus on quiet withdrawal but on Spinoza's political philosophy, praising his contributions to democratic-republican thought and focusing on the relationship between autonomy and power (potentia). Potentia signifies, Zhang argued, how the myriad things (wanwu 萬物) receive power (quanli 權力) and movement (dong 動) from a self-generative (ziyin 自因) god (shen 神) and nature (ziran 自然) as expressions for one and the same reality.

15 Fichte is discussed in Driesch's eighth lecture in China and was translated by Zhang and Qu (Driesch 1923).

16 Zhang's translation is of Eucken's 1921 edition. On Eucken's activist idealist and nationalist reception of Fichte, see Fulda 2010, 107-50.

17 On Fichte, socialism, and Marxism, see Weber 1900; Rockmore 1982.

18 Compare the illuminating discussion of Hu's and Zhang's Spinoza essays in Gálik 1975, 29-43. 
Zhang depicted Spinoza as a thinker of how to unify heart-mind and things (he xinwu 合心物). There are two philosophical problems that he draws from this analysis: (1) how are intuition and the concept (or conceptual reasoning) one in intellectual contemplation (jingguan 靜觀)? (2) how are right (quanli 權利) and power (quanli 權力) one and the same in Spinoza's equation of ethics with natural desire (conatus) and the ability (potentia) to act out of oneself?

First, Zhang's philosophical works increasingly endeavoured to answer the first question emerging from his interpretation of modern Western philosophy by retrieving Chinese philosophical discourses within an explicitly modern perspective. Zhang's conception of modernity, and his underlying phenomenology of the lifeworld and its implicit rationality, is explicitly intercultural. A hermeneutical retrieval of this dimension of his works thus provides a significant alternative to the Eurocentric conceptions of reason and the lifeworld developed by thinkers such as Husserl and Habermas. ${ }^{19}$

Zhang did not externally impose a traditional Confucian paradigm onto the modern philosophical discourse, nor did he appeal to the idea of a special form of Chinese or "Oriental intuition" that has been critiqued in accounts of "New Confucianism" ( $x$ in rujia 新儒家) as a self-Orientalizing (or “inverted” Orientalist) reaction to Western modernity. ${ }^{20}$ Instead, pursuing a strategy akin to Misch and Husserl, Zhang elucidated the rationality (which — as in Husserl and Habermas-is more deeply rooted than logical rules for thinking) inherent in each form of historical life or lifeworld that is made reflective in philosophy. ${ }^{21}$ Confucian discourses are not merely expressions of irrational Oriental intuition. They indicate a model of rationality that could encompass the affective, intuitive, and intersubjectively attuned dimensions of human life rather than exclude them as merely subjective and irrational. ${ }^{22}$ Zhang is compelled by his interpretation of the Chinese lifeworld, which has its own rationality, to rehabilitate the Neo-Confucian philosophy of the heart-mind that can encompass the contradictions of intuition and rationality, subjectivity and objectivity, and the mediation of heart and things (the "internal" and "external" world).

Secondly, Zhang praised Spinoza as the thinker of the modern freedom of the individual, in which the equivalence of power and right is the basis of the "spiritual

19 I develop this interpretation of the lifeworld and rationality in Husserl and Habermas and the need for its intercultural reinterpretation in chapter six of Nelson 2017.

20 Compare the discussion of "New Confucianism" and "inverse Orientalism" in Ge 2017, 241-85.

21 On Misch and Husserl on lifeworld, breakthrough, and reflection, see chapters five and six of Nelson 2017.

22 On the importance of the affects in ethical life and broader conception of the rational in the Confucian lineage, see Nelson 2018a, 193-204. 
freedom" that entails the entire range of freedoms of and rights to thought, speech, and publication suppressed under the Nationalist regime. Spinoza introduced a new conception of the nation in which the individual is not merely subordinated as a part of the whole. Zhang's political writings of this period are shaped by nationalist concerns in conjunction with liberal, republican, and social democratic discourses and their Chinese reception that he helped promote. They are concerned, particularly in the period of the Japanese occupation of China, with the salvation of the Chinese people through the development of its capacity for autonomy and self-power. The former is identified with establishing a liberal constitutional political order guaranteeing fundamental human, political, and social rights, and the latter with the expression and cultivation of the Chinese nation in response to its abject semi-colonial condition.

How is Zhang's interpretation of Spinoza's potentia, with its identification of right and power, to be understood? On the one hand, there is the philosophical question of power. In this discussion of self-motivating power in Spinoza, Zhang appears committed to a generally naturalistic and secular life-view as much as $\mathrm{Hu}$ Shi, while opposing reductive scientistic naturalism. Both the instrumentalist and life-philosophical variations on naturalism are haunted by the problem of the "naturalistic fallacy" of deriving the normative (the guiding "ought") from the factual (the "is").

On the other hand, power is connected to the ideas of national survival and self-assertion operative in Zhang's political discourse of the 1930s on national revival in The Academic Foundation for National Revival (Minzu fuxing zhi xueshu jichu 民族復興之學術基礎 (1935)) and the 1934 English language essay “National Renaissance Historically Considered" in which he utilized the identification of right and power in describing the Sino-Japanese conflict and Chinese survival. Dikötter has described how Zhang held a multi-ethnic concept of the Chinese nation, defined by common cultural connections and interests rather than race and blood (Zhang 1935; Zhang 1934, 708-10). ${ }^{23}$ The destruction of an interrelated family of languages and cultures (i.e., a social-historical lifeworld) is consequently the destruction of a people. As in the conclusion of his discussion of China's constitutional crisis in 1931, brought about by the Nationalist Party's postponement of democratic reforms, Zhang again described the international arena in social Darwinist language as a "struggle for existence" (Daseinskampf) between peoples. ${ }^{24}$ As in Sun Yat-sen's image of heaps of "loose sand" (yipan sansha

23 Frank Dikötter has examined Zhang's rejection of racial purity and common blood in Dikötter 2015, 182.

24 On the Chinese reception and adaptation of Darwinism, see Jones 2011; Shen 2015, 49-60. 
一盤散沙), the Chinese people are depicted as lacking and in desperate need of finding the self-confidence and self-respect that arises through an appropriate relation to their own history and heritage for the sake of future developmentand without which they will be scattered by the forces of history (Zhang 1934, 708-10). The construction of a bifurcation and opposition between tradition and modernity, maintained by both traditionalists and their New Culture opponents, is self-defeating, since Chinese modernization cannot appropriately occur without an authentic, living connection with the Chinese past. As he concluded in a German essay on Confucianism published in Richard Wilhelm's journal Sinica in 1930, there is a need for a relationship with one's own tradition for the sake of one's present and future condition (Zhang 1930a, 226). Zhang recognized in this analysis how the constructive relationship with tradition (such as Confucianism in China) is a condition of and vehicle for the cultivation of individual autonomy and social solidarity. As Husserl and Habermas have maintained, in their own ways in relation to consciousness and communicative action, the lifeworld is the condition of modernization and reform rather than an impediment to be colonized and eliminated.

The republican idea of popular self-determination offered Zhang in 1934 a primary motivation for his interpretation of historical life and the lifeworld. Preserving contact with and reviving past forms of Chinese intellectual and cultural life would reintegrate the past and the present. Furthermore, at the same time as a reconceptualization of Confucianism indicated a way of responding to the modern philosophical crisis of reason, a theme Zhang adopted from Eucken and shared with the German intellectual tradition of Husserl, his concerns with the social-political crises of colonial modernity led to a transition from the Western discourse of nationalism, as the people's self-expression and self-assertion, to a vision of a progressive reconstruction of Confucian lifeworlds and their ethical and political discourses. This modern intercultural reconstruction would provide the motivational context and bases for modern Chinese society in contrast to the deficits of the Nationalist and Communist parties that determined China's subsequent fate.

\section{A Modern Confucian Critique of Chinese Modernity}

Hegel remarked that the Enlightenment is unenlightened about itself (Hegel 1978, §§549-50). From Hegel's Phenomenology of Spirit to The Dialectic of Enlightenment of Horkheimer and Adorno, modernity is interpreted as demanding its own self-critique (that is, a critique encompassing the modern as well as 
the premodern) in contrast to a dogmatically conceived opposition between the old and the new, faith and reason, or tradition and its disruption (Hegel 1978; Horkheimer and Adorno 2002). ${ }^{25}$ An early twentieth-century Chinese example of self-critical modernity engaging its dialectic is visible in Zhang's confrontation with notions of Enlightenment, progress, and modernity that contests the dichotomies of tradition/modernity and Occident/Orient presupposed by Chinese traditionalist and Westernizing discourses (evident in Hu Shi's positivistic and scientistic response to Zhang's 1923 lecture on science and lifeview) during the Republican era (Hu 2007, 225; Egan and Zhou 2009, 176).

As noted above, Zhang endorsed the initial national and democratic goals of the May Fourth student movement. He did, however, critique its interpretation and appropriation by the New Culture and communist movements that he judged to undermine Chinese national self-interest and democracy. It was these modern cultural and social-political concerns that led Zhang into conflict with iconoclastic "modernizing" forces (nationalist, technocratic liberal, and communist) for social-political, cultural, and philosophical reasons.

First, one primary criticism concerned totalitarianism and pluralism, the state and civil society. Already in the 1920s, Zhang was concerned with the priority of the state and the emergence of totalitarianism in China. His 1931 German article "The Constitutional Crisis of the Chinese Republic" (Die staatsrechtliche Krisis der chinesischen Republik) unfolded a critique of the Chinese constitutional crisis introduced by what he portrayed as the increasing totalitarianism of the nationalist one party state (Zhang 1931a, 316-55). Zhang identified the theory of the one-party state, and its communist and fascist incarnations in Lenin and Mussolini, with the rule of the Chinese Nationalist Party (Zhongguo Guomindang 中國國民黨) (ibid.). The tutelage of the one party state cannot provide an appropriate opening to a flourishing multi-party democracy to the extent that it undermines its conditions by failing to guarantee fundamental legal and political rights (Grundrechte) and disallowing the long-term habits and practices of civil society that help make a people capable of democracy (ibid., 354).

In this essay, in contrast to the four types of crisis identified in his 1922 essay discussed later in this work, Zhang adopted the notion of "constitutional crisis" from the contemporary German crisis discourse of the waning Weimar Republic (Zhang 1922a, 117-23). His critical analysis of the one-party state relied on German legal theorists who opposed the multi-party democratic state and supported National Socialism. He cited, for instance, two texts by Otto Koellreutter and

25 On the problematic of modernity in Adorno and critical social theory, see Nelson 2020. 
three by Carl Schmitt, including in the conclusion concerning the necessity of the national state given the struggle for existence between nations (Zhang 1931a, $338,244,355) .{ }^{26}$ Whereas the idea of national survival justified the anti-democratic revolution that overturned the Weimar Republic in the works cited by Koellreutter and Schmitt, achieving a democratic constitutional order was a fundamental requirement of national survival in Zhang's argument.

The May Fourth students' demand for the constitutional institutionalization and public practice of democracy was never realized and-in Zhang's harsh assessment that already began to form in the 1920s and which he judged to be confirmed by subsequent events - was betrayed by the Westernizing May Fourth and New Culture intellectuals. In a dire judgment of recent Chinese history, Zhang contended that the constitutional and democratic deficits of the nationalist politics of Sun Yat-sen undermined the legal institutionalization and popular public practice of democracy. This deferral prepared the way for Nationalist dictatorship in 1927. He repeated this negative assessment concerning China's failure to become a democratic constitutional state in his 1952 The Third Force in China (Zhang 1952, 53-69). The Chinese lifeworld was being undermined in two ways: while the Nationalist Party created a social vacuum that destroyed the social-political conditions for democratizing China, the New Culture Movement created a spiritual vacuum by destroying its cultural and intellectual (spiritual) conditions (Zhang 1962a, 411). In contrast to the radical bifurcation and opposition of tradition and modernity, which is posited by homogenizing theories of modernity, the realization of modernity requires a more appropriate and flexible relationship with traditions. To utilize Habermas's language of system and lifeworld, there should be a non-colonizing relationship between the forces of instrumental rationalization (promoted by $\mathrm{Hu}$, Ding, and the New Culture Movement) and the complex multi-layered historical lifeworld (Habermas 1984).

Zhang is notorious for his stubborn, almost hopeless opposition to the Nationalist and Communist deferral of fundamental human rights for the Chinese people and his demand for the immediate introduction of democratic rights and institutions that would encourage the governmental separation of powers, a plurality of political parties and forces, and the formation of a flourishing public sphere and civil society that was deeply rooted in the Chinese tradition itself and that he articulated in relation to the political philosophies of Kant and Hegel. ${ }^{27}$

Hegel's Philosophy of Right (1820) preserved a number of the achievements of Enlightenment political thought while seeking to moderate its radical implications.

26 On their roles in the politics of National Socialist Germany, see Caldwell 1994, 399-427.

27 On the complexity of the contemporary Chinese discourse of civil society, see He 1997. 
As Herbert Marcuse explored in his classic work Reason and Revolution, Hegel's social-political implications were highly contested by adherents and critics on the right and the left (Marcuse 1960). Hegelian political discourse played multifarious roles in Chinese political discourses of the 1930s, as seen in He Lin 賀麟 and the "Zhanguoce School” (戰國策, “Strategies of the Warring States”) (see Wong 2018, 616-33; also note Guo 2009 45-69). In his early 1930s lectures on Hegel's Philosophy of Right, Zhang did not interpret Hegel merely as an apologist of the priority of state. Hegel is interpreted as a theorist of (1) the mediation of powers in the constitutional state and (2) the mediating spheres of the family and civil society (bürgerliche Gesellschaft, gongmin shehui 公民社會). The social function of the family and civil society are also key features of the Confucian reformist tradition and its critique of existing political realities. Civil society encompassed a plurality of forms of association and social-life between the individual and the state. Zhang elucidated the key element of modern democratic political philosophy that stands in opposition to the totalitarian obliteration of civil society to the state. This point is made again in his 1967 Singaporean lectures on democratic socialism, near the end of his life, in which he deployed Hegel's concept of "civil society" to critique capitalism, communism, and fascism as the one-sided reification of respectively self-interest, society, and the state as the highest end of social-political life (Zhang 2015, 15-19).

Second, as we noted in his interpretation of Fichte's Addresses, autonomy must be self-motivated rather than externally imposed. Furthermore, Zhang's phenomenology of the lifeworld led him to the conclusion that democratic institutions require a democratic culture and motivations that Zhang thought could be adopted and reconstructed from Chinese traditions.

Zhang prefigures the contemporary idea of intercultural philosophy. He opposed both the complete Westernization of Hu and Ding and the reactive self-Orientalism of Chinese traditionalists, expressing scepticism of the very idea of the superiority of either Eastern or Western civilization in the 1922 essay "The Crisis of European Culture and the Tendency of New Culture in China", in a way that can help resituate Husserl's more limited interpretation of crisis in his writings of the 1920s and 1930s on crisis and renewal. Echoing Kant's account of autonomy in "What is Enlightenment?", Zhang rejected both Chinese traditionalism and New Culture Westernization in this essay, suggesting that emancipation from false prejudices required a critical relation to both Eastern and Western civilization that faced both their limitations and crises. Using the discourses of life-philosophy and socialism, he diagnosed the crisis of modernity as both a spiritual crisis of reason and a social-political crisis of capitalism (Zhang 1922a, 117-23). Zhang succinctly stated his ethos of individuality and the social in his 1923 lecture on lifeviews: 
intellectual development should be personal; property distribution should be social (“智識發展, 應重個人; 財產分配, 應均諸社會”) (Zhang 1996, 118).

Zhang repeatedly stated from the 1920s to the 1960s-notably, for instance, in the introduction to his most internationally recognized political work The Third Force in China - that the New Culture Movement could not prepare the Chinese for autonomy and a flourishing and functional democracy. A modernized Confucian ethos was the route to autonomy and democracy in the Chinese context, such that a destructive relation with the past would eliminate its very conditions. Zhang's analysis reveals his affinities with Western thinkers of the integrity of ethical life (Hegel), historical life (such as Dilthey and Georg Misch), and the lifeworld (Husserl and Habermas). He explicitly connected the iconoclasm of the May Fourth Movement (or, at least, its appropriated form in the New Culture Movement) with communist iconoclasm, contending that the destruction of tradition was preparation for tutelage and totalitarianism (Zhang 1952, 47). Zhang accordingly identified in The Third Force in China the literary anti-Confucian revolution as the preliminary preparation for the right-wing totalitarianism of the Nationalist Party, which was hindered by its own corruption and incompetence in Zhang's estimation, and the left-wing totalitarianism of the Communist Party (Zhongguo Gongchandang 中國共產黨) (ibid.).

Third, Zhang differentiated in his 1965 Seoul lecture the distinct threads that were subsequently identified with the idea of the May Fourth Movement. Four tendencies in particular that should be distinguished are:

1. Literary and linguistic transformation from classical to vernacular culture.

2. Sexual transformation from sexual restraints and hierarchical gender inequality to free love and gender equality.

3. Democratic transformation from authority to freedom.

4. Scientific transformation from superstition and subjectivity to evidential knowledge (Zhang 1965, 91).

Zhang offered two responses to these four forms of transformation. One argument addresses how modernity and Confucianism are not merely compatible, based on an understanding of the ethos of the lifeworld, but reinforce and mutually establish each other. The reconstruction of the progressive aspects of Confucianism in his works on its history accentuated figures such as Mengzi 孟子 and Wang Yangming, which he interpreted as rational and reformist (Zhang 1957; 1962a; 1962b; 2016). He reinterpreted Confucianism as a guiding ethos and philosophical way of living that can be differentiated and separated from its flawed forms of institutionalization and practice. As an ethos 
of universal benevolence and responsiveness to the interests of the people, it is compatible with and can guide and extend the cultural and social-political reform of a way of life.

A second argument concerns the need to recognize the potential deficits and limitations of modernization and Westernization if they are not to become destructive and undermine their own aims. Zhang took up the argumentation of 1923 again in 1965 in Seoul, stressing the plurality and complexity of the modern situation and the necessity of a self-critical rather than a dogmatic conception of modernity. In a pluralistic and multifaceted modernity, the new is critically interconnected with the old, freedom with an order that allows it to flourish, and science with cultural and ethical concerns. Zhang's phenomenological and political analyses indicate ways of rethinking modernity, rationality, and the lifeworld-beyond the Occidentalist oriented paradigms of rationalization in Husserl and Habermasin the Chinese context and more broadly.

\section{Conclusion: An Intercultural Discourse of Modernity}

Zhang and other Chinese intellectuals did not passively accept European philosophical and socialist discourses as Eurocentric theories of modernization assume. In the case of Zhang's discourse, modernization occurs in opposition to complete Westernization. The problematic one-way street model of modernity, globalization, and Westernization encompasses advocates (such as Husserl and Habermas) and critics (such as Heidegger) of modernity, as I argued in my 2017 book. It evades the actuality that modernity has multiple cultural and social-political origins. Modernization is "creolized", both mediated and fractured, by resistances from the subjugated margins rather than being a purely Occidental formation. Revisiting Zhang's works in relation to phenomenology and critical social theory, represented respectively by Husserl and Habermas in this article, indicates a needful intercultural reorientation of both.

The case of Zhang Junmai indicates how a "conservative" "anti-May Fourth" intellectual shared many of its commitments with two conspicuous differences; he was more radically committed to constitutional democracy, which dwindled away into a weak "third force", and rejected its totalizing anti-traditionalism and commitment to naïve one-dimensional positivist-pragmatist ideas of modernity and Westernization. The crisis of the breakdown of the authority of the classical canon and the traditional Confucian paradigm did not entail its end for Zhang, as it did for the New Culture Movement. It was rather another transformation, shaped by internal and external ideas and historical forces, in 
its evolving history that would continue to play a significant role in Chinese modernities. $^{28}$

Zhang's growing articulation of a modern “New Confucian” (xin rujia 新儒家) philosophy, centring on moral autonomy and critically drawing from and redeploying Chinese classical sources, particularly after the Communist victory and his subsequent exile to the United States, has roots in and altered his earlier conception of nationalism that was conceived in relation to republican (Spinoza, Kant), nationalist (Fichte, Eucken), as well as social democratic (Laski) sources and models. ${ }^{29}$ The traditionalist and conservative interpretation of Confucianism led to the suspicion-one shared by contemporary "New Confucian" critics of the earlier generation - that Zhang's approach was more Kantian and indeed Western than genuinely Confucian and Chinese. ${ }^{30}$ Zhang's discourse is not purely traditionalist nor neoconservative in any narrow sense, unless one can speak of an intercultural progressive traditionalism. It is also not merely derivative of modern or globalized Western discourses that deny the agency and subjectivity of thought and practice to those outside the West. It is a highly mediated modern intercultural response to the perils and perplexities of Chinese modernity that it failed to overcome.

It is in this context of a critical fused, hybrid, or mixed (that we can retrospectively designate "intercultural" or "creolized") conception of modernity that Zhang should be reinterpreted. This argument includes his rejection of the specious either/or of Chinese tradition and complete Westernization, Sinocentrism and Eurocentrism-as illustrated above in his 1922 essay "The Crisis of European Culture and the Tendency of New Culture in China" (a work that supplements and corrects Husserl's 1936 discourse of crisis in The Crisis of European Sciences and Transcendental Phenomenology: An Introduction to Phenomenological Philosophy) and in his mature conception of a modern intercultural Confucian philosophy (Zhang 1922a, 117-23; Husserl 1970). Zhang's alternative phenomenological and social-political strategies indicate a potential intercultural path that was not taken and judged a historical failure in subsequent hegemonic narratives. However, such a historical judgment of failure itself presupposes a problematic homogenizing teleological of narrative of modernity, including Chinese modernity, and the May Fourth and other historically related movements.

28 Compare his argument concerning the modern role of the Confucian classics after their loss of authority in Zhang 1931b, 106.

29 On the "New Confucian" movement, see Makeham 2003; Rosker 2016; Van den Stock 2016.

30 Compare the discussion after the Seoul lecture in Zhang 1965, 99. On the new generation's conservative suspicions concerning the liberalism of earlier New Confucianism, see Ge 2017,241-85. 
Habermas, as a contemporary theorist and defender of modernity as rationalization, aptly argued in The Philosophical Discourse of Modernity that paths not taken remain significant keys for interpreting the paths that were taken and for formulating alternatives for contemporary questions (Habermas 2004). Given its historical finitude and limitations, Zhang's path is still suggestive for interpreting the historical formation of the idea of the May Fourth Movement and its consequences that contests Whig and teleological historical narratives of modernity and involves the recognition of their belatedness, discursive and ideological construction, and functional multiplicity in actual discourses in contrast to their homogenous, idealized form.

Habermas's point about paths not taken in The Philosophical Discourse of Modernity can be applied to his own conception of Occidental reason and its history that retains its hegemonic role. First, the Chinese "periphery" reveals aspects of modernity that are invisible in its Western "centre". Second, the complex historical constellation addressed in this article offer hints and clues to disentangling the problematic of modernity itself that a contemporary Western thinker such as Habermas-relying on a reconstruction of Max Weber's Occidentalist narrative of the history of rationality-continue to construe exclusively in Western terms without an adequate conception of "non-Western", intercultural, "creolized", and other alternative modernities. ${ }^{31}$

\section{References}

\section{Works of Zhang Junmai [Carson Chang]}

Chang, Carsun. 1919. "China and the League of Nations." South China Morning Post, October 23, 1919.

Chang, Carsun, and Rudolf Eucken. 1922. Das Lebensproblem in China und Europa. Leipzig: Quelle und Meyer.

Zhang, Junmai 張君勱. 1922a. “Ouzhou wenhua zhi weiji ji Zhongguo xin wenhua zhi quxiang 歐洲文化之危機及中國新文化之趨向 (The Crisis of European Culture and the Tendency of the New Culture in China)." Dongfang zazhi 東方雜誌 (The Eastern Miscellany) 13 (3): 117-23.

—. 1922b. Xin Deguo shenhui minzhu zhengxiang ji 新德國社會民主政象記 (The Image of New German Social Democratic Politics). Shanghai: Shangwu yinshuguan.

—, ed. 1924. Kexue yu rensheng guan 科學與人生觀 (Science and Life-Vierw). Shanghai: Yadong tushuguan.

31 Note the role of the Occident in his latest work Habermas 2019. 
—. 1926. “Aiguo de zhexuejia: Feixide 愛國的哲學家: 菲希德 (A Patriotic Philosopher: Fichte).” Dongfang zazhi 東方雜誌 (The Eastern Miscellany) 23 (10): 71-77.

—.1928a."1919 nian zhi 1921 nian lü ou zhong zhi zhengzhi yinxiang ji wuren suode zi jiaoxun 1919 年至1921年旅歐中之政治印象及吾人所得之教訓 (Political Impressions and Lessons of traveling in Europe from 1919 to 1921).” Xinlu 新路 (The New Way) 1 (5): 21-24.

—.1928b. "Yingguo xiandai zhengzhi xuezhe lai si ji shi xueshuo 英國現代政 治學者賴司幾氏學說 (The Modern British Political Theorist Laski).” Xinlu 新路 (The New Way) 1 (7): 35-36.

Chang, Carsun. 1930a. "Die Hauptfragen in der konfuzianischen Philosophie." Sinica 5 (1): 213-26.

Zhang, Shilin 張士林. 1930b. Zhengzhi dianfa 政治典範 (A Grammar of Politics). Translated by Harold Laski 拉斯基. Shanghai: Shangwu yinshuguan.

Chang, Carsun. 1931a. "Die staatsrechtliche Krisis der chinesischen Republik." Jabrbuch des öffentlichen Rechts der Gegenwart 19: 316-55.

—. 1931b. "Die Stellung der Kanonischen Literatur im modernen Geistesleben Chinas." (Part two) Sinica 6 (3): 97-108.

—. 1934. "National Renaissance Historically Considered." The China Critic 7 (29) (July, 19): 708-10.

Zhang,Junmai 張君勱. 1935. Minzu fuxing de xueshu jichu 民族復興之學術基礎 (The Academic Foundation for National Revival). Beijing: Zai sheng she.

Chang, Carsun. 1952. The Third Force in China. New York: Bookman Associates.

- 1957/1962a. The Development of Neo-Confucian Thought, vol. 1 and 2. New York: Bookman Associates.

—. 1962b. Wang Yang-ming: Idealist Philosopher of Sixteenth-Century China. Jamaica, NY: St. John's University Press.

- 1965. "Modernization of China and Revival of the Philosophy of the Confucian School." Proceedings of the Conference on the Problems of Modernization in Asia, Seoul, Korea, June, 28-July, 7, 1965. Seoul: Asiatic Research Center, Korea University.

Zhang, Junmai 張君勱. 1996. Zhang Junmai juan 張君勱卷. Shijiazhuang: Hebei jiao yu chuban she.

—. 2015. Shehui zhuyi sixiang yundong gaiguan 社會主義思想運動概觀 (An Overview of the Socialist Movement). Taipei: Xin wenfeng chuban gongsi.

Chang, Carsun. 2016. Geschichte Der Neukonfuzianischen Philosophie: Vom 10. Jahrhundert Bis Zur Mitte des 13. Jahrbunderts, edited by Joseph Ciaudo, and Heiner Roetz. Frankfurt: Klostermann. 


\section{Other Works}

Arendt, Hannah. 1968. The Origins of Totalitarianism. New York: Harcourt, Brace and World.

Briere, O. 1956. Fifty Years of Chinese Philosophy, 1898-1950. Translated by Laurence G. Thompson. London: George Allen \& Unwin.

Butterfield, Herbert. 1931. The Whig Interpretation of History. London: Bell.

Caldwell, Peter. 1994. "National Socialism and Constitutional Law: Carl Schmitt, Otto Koellreutter, and the Debate over the Nature of the Nazi State, 19931937." Cardozo Law Review 16: 399-427.

Chen, Xiaoming. 2007. From the May Fourth Movement to Communist Revolution. Albany: State University of New York Press.

Chow, Kai-wing, Tze-ki Hon, Hung-yok Ip, and Don C. Price, eds. 2008. Beyond the May Fourth Paradigm: In Search of Chinese Modernity. Lanham: Lexington Books.

Dikötter, Frank. 2015. The Discourse of Race in Modern China. New York: Oxford University Press.

Driesch, Hans. 1923. Dulishu Jiang Yan Lu 杜里舒講演錄. Translated by Zhang Junmai 張君勱 and Qu Shiying 篗世英. Shanghai: Shangwu yinshuguan.

Egan, Susan C., and Zhiping Zhou. 2009. A Pragmatist and His Free Spirit: The Half-Century Romance of Hu Shi and Edith Clifford Williams. Hong Kong: Chinese University Press.

Fang, Weigui. 2019. Modern Notions of Civilization and Culture in China. Singapore: Springer.

Fichte, Johann Gottlieb. 1921. Fichtes Reden in Kernworten. Ausgewählt von Rudolf Eucken. Leipzig: Meiner./Chinese edition: Zhang, Junmai 張君勱, translator. 1932. Feixide dui Deyizhi guomin jiangyan 菲希德對德意志國民 講演. (Fichte's Addresses on the German Nation). Beiping: Zaisheng zazhishe.

Fulda, Hans Friedrich. 2010. "Neufichteanismus in Rudolf Euckens Philosophie des Geisteslebens?” Fichte-Studien 35: 107-50.

Fung, Edmund S. K. 2009. "Nationalism and Modernity: The Politics of Cultural Conservatism in Republican China." Modern Asian Studies 43 (3): 777-813.

Fung, Edmund S. K. 2010. The Intellectual Foundations of Chinese Modernity: Cultural and Political Thought in the Republican Era. New York: Cambridge University Press.

Gálik, Marián. 1975. "Two Modern Chinese Philosophers on Spinoza (Some Remarks on Sino-German Spinoza's Festschrift." Oriens Extremus 22 (1): $29-43$.

Ge, Zhaoguang 葛兆光. 2017. "Yixiang tiankai: Jinnian lai dalu xin ruxue de zhengzhi suqiu 異想天開：近年來大陸新儒學的政治訴求 (If Horses Had Wings: The Political Demands of Mainland New Confucians in Recent Years).” Sixiang 思想 (Thought) 33: 241-85. 
Guo, Ping 郭萍. 2017. Ziyou ruxue de xian sheng: Zhang Junmai ziyou guan yanjiu 自由儒學的先聲: 張君勱自由觀研究 (The Pioneer of Free Confucianism: A Study of Zhang Junmai's View of Freedom). Jinan: Qilu shushe.

Guo, Wu. 2009. “The 'Zhanguoce' School's Effort of Wartime Cultural Reconstruction, 1940-1942." Journal of Modern Chinese History 3 (1): 45-69.

Habermas, Jürgen. 1984. The Theory of Communicative Action: Liferworld and Systems: A Critique of Functionalist Reason, vol. 2. Boston: Beacon Press.

—. 1995. "Reconciliation through the Public Use of Reason: Remarks on John Rawls's Political Liberalism.” The Journal of Philosophy 92 (3): 109-31.

- 2004. The Philosophical Discourse of Modernity. Cambridge: MIT Press.

- 2019. Auch eine Geschichte der Philosophie. Frankfurt: Suhrkamp.

He, Baogang. 1997. The Democratic Implications of Civil Society in China. London: Macmillan Press.

Hegel, Georg W. F. 1978. Phenomenology of Spirit. Oxford: Clarendon Press.

Hon, Tze-ki. 2015. The Allure of the Nation: The Cultural and Historical Debates in Late Qing and Republican China. Leiden: Brill.

Horkheimer, Max, and Theodor W. Adorno. 2002. Dialectic of Enlightenment. Stanford: Stanford University Press.

$\mathrm{Hu}$, Shi 胡適. 1932. “Sibinnosha yu Zhuangzi” 斯賓諾莎與莊子 (Spinoza and Zhuangzi) and Zhang Junmai 張君勱, Sibinnnisha zhi zhengzhi zhexue (Spinoza's Political Philosophy). In Dem Andenken Spinozas. Tientsin-Peiping: Peiyang Press.

Hu Shi 胡適. 2007. Hu Shi quanji 胡適全集 (The Complete Work of Hu Shi). Hefei: Anhui jiaoyu chubanshe.

Husserl, Edmund. 1970. The Crisis of European Sciences and Transcendental Phenomenology: An Introduction to Phenomenological Philosophy. Evanston: Northwestern University Press.

—. 1987. "Fichtes Menschheitsideal.” In Aufsätze und Vorträge (1911-1921), edited by Thomas Nenon and Hans Reiner Sepp, 267-92. Dordrecht: Martinus Nijhoff Publishers.

—. 1995. "Fichte's Ideal of Humanity." Husserl Studies 12 (2): 111-33.

James, David. 2015. Fichte's Republic: Idealism, History and Nationalism. Cambridge: Cambridge University Press.

Jeans, Roger B. 1997. Democracy and Socialism in Republican China: The Politics of ZhangJunmai (Carsun Chang), 1906-1941. Lanham: Rowman and Littlefield.

Jones, Andrew F. 2011. Developmental Fairy Tales. Cambridge: Harvard University Press.

Kohn, Hans. 1949. “The Paradox of Fichte's Nationalism." Journal of the History of Ideas 10 (3): 319-43.

Korsch, Karl. 2001. Gesamtausgabe: Briefe 1940-1958, vol. 9. Amsterdam: Europäische Verlagsanstalt. 
Lin, Yusheng. 1979. The Crisis of Chinese Consciousness: Radical Antitraditionalism in the May Fourth Era. Madison: University of Wisconsin Press.

Makeham, John, ed. 2003. New Confucianism: A Critical Examination. New York: Palgrave Macmillan.

Marcuse, Herbert. 1960. Reason and Revolution: Hegel and the Rise of Social Theory. Boston: Beacon Press.

Mittler, Barbara. 2018. "The View from China: r/Renaissances." In Why China Did Not Have a Renaissance - and Why That Matters: An Interdisciplinary Dialogue, edited by Thomas Maissen, and Barbara Mittler, 83-119. Berlin: Walter de Gruyter.

Nelson, Eric S. 2013. "Heidegger and Carnap: Disagreeing about Nothing?” In Bloomsbury Companion to Heidegger, edited by François Raffoul and Eric S. Nelson, 151-56. London: Bloomsbury Press.

—. 2017. Chinese and Buddhist Philosophy in Early Twentieth-Century German Thought. London: Bloomsbury.

—. 2018a. "Confucian Relational Hermeneutics, the Emotions, and Ethical Life." In Relational Hermeneutics: Essays in Comparative Philosophy, edited by Paul Fairfield and Saulius Geniusas, 193-204. London: Bloomsbury.

- 2018b. "Dilthey and Carnap: Eliminating Metaphysics, the Feeling of Life, and the Scientific Worldview." In The Worlds of Positivism: A Global Intellectual History, 1770-1930, edited by Johannes Feichtinger, Franz L. Fillafer, and Jan Surman, 321-46. New York: Palgrave.

- 2020. (Forthcoming). Levinas, Adorno, and the Ethics of the Material Other. Albany: State University of New York Press.

Rockmore, Tom. 1982. Fichte, Marx, and the German Philosophical Tradition. Carbondale: Southern Illinois University Press.

Rošker, Jana S. 2016. The Rebirth of the Moral Self. Hong Kong: Chinese University Press.

Schwarcz, Vera. 1986. The Chinese Enlightenment: Intellectuals and the Legacy of the May Fourth Movement of 1919. Berkeley: University of California Press.

Shen, Tsing-song Vincent. 2015. "Evolutionism through Chinese Eyes: Yan Fu, Ma Junwu and their Translations of Darwinian Evolutionism." ASLANetwork Exchange: A Journal for Asian Studies in the Liberal Arts 22 (1): 49-60.

Sun Yat-sen 孫逸仙. 1996. Sanmin zhuyi 三民主義 (The Three Principles of the People), 18th ed. Taipei: Sanmin Press.

Tan, Sor-hoon. 2003. Confucian Democracy: A Deweyan Reconstruction. Albany: State University of New York Press.

Tan, Sor-hoon. 2012. "The Pragmatic Confucian Approach to Tradition in Modernizing China." History and Theory 51 (4): 23-44.

Van den Stock, Ady. 2016. The Horizon of Modernity: Subjectivity and Social Structure in New Confucian Philosophy. Leiden: Brill. 
Wang, Fan-sen 王汎森. 2019. “Tansuo Wusi lishi de liangtiao xiansuo 探索五四 歷史的兩條線索 (Two Threads to Approach the History of May Fourth).” Ershiyi shiji 二十一世紀 (Twenty-First Century) 172: 18-31.

Wang, Jessica Ching-Sze. 2007. John Dewey in China: To Teach and to Learn. Albany: State University of New York Press.

Weber, Marianne. 1900. Fichte's Sozialismus und sein Verbältnis zur Marx'-schen Doktrin. Tübingen: J. C. B. Mohr.

Wong, Tung Tin. 2018. "He Lin and German Philosophy in the Zhanguoce School: An Idealist Philosopher on History and Cultural Reform.” Frontiers of Philosophy in China 13 (4): 616-33.

Wong, Young-Tsu. 1993. "The Fate of Liberalism in Revolutionary China: Chu Anping and His Circle, 1946-1950.” Modern China 19 (4): 457-90.

Wu, Shengqing. 2013. Modern Archaics: Continuity and Innovation in the Chinese Lyric Tradition, 1900-1937. Cambridge: Harvard University Asia Center Press.

Yu, Ying-shih 余英時. 2018. Yu Ying-shib huiyi lu 余英時回憶錄 (Yu Ying-shib's Memoir). Taipei: Yunchen wenhua.

Zhang, Wei. 2010. What is Enlightenment: Can China Answer Kant's Question? Albany: State University of New York Press. 